\title{
Cooperative Mechanism for Solving Conflicts in Infrastructure Projects
}

Konrad Spang
University of Kassel, Germany
spang@uni-kassel.de
DOI 10.5592/otmcj.2012.2.10

Research paper

\author{
Stefan Riemann \\ University of Kassel, Germany \\ riemann@uni-kassel.de
}

\author{
Helmut Köntges \\ International Project Management, Germany \\ koentges.ipm@t-online.de
}

Research paper

RISKS AND UNCERTAINTIES ARE QUITE COMMON IN PROJECTS IN GENERAL AND IN LARGe and COMPlex infrastructure Projects in SPeCial. Sometimes these risks can cause conflicts and disputes, which cannot be solved between the contracting parties. A lawsuit often would be the only way to solve the conflict. To avoid going to court, several variations for conflict solution have been established. After an introduction into the topic of these mechanisms, a research project will be presented. In this project the adjudication model is incorporated into a recent guideline for partnering in the construction of civil infrastructure projects. The findings of the testing phase of this guideline in real construction project are all in all very good. The solutions came faster and the costs were lower than in a court process. Some disputes were even solved without an adjudication process, but with the help of the adjudicators.

\section{INTRODUCTION}

Construction projects and especially civil infrastructure projects are becoming more and more complex. Hence, it is not surprising that conflicts between the contracting parties may arise during the construction period (Spang and Riemann, 2011). This is explained by the nature of the projects themselves since they are unique phenomena often taking several years and including many parties and stakeholders. Some conflicts can be solved by a court of law only years after the actual completion of the construction project. However, participants complain not only about the tediousness of the procedure, which ultimately can also be ascribed to overloaded courts, but also about the quality of the rulings since the courts often lack specialization on construction law (Gralla and Sundermeier, 2008). This negative impression about rulings is supported by the fact that mostly there is a 'winner' and a 'loser'. At this stage it is often too late for solutions where both parties come out satisfied with the negotiations. Therefore, it makes sense to solve conflicts as early as possible in order to avoid court proceedings and ultimately the associated litigation costs (Jannadia et al., 2000). 


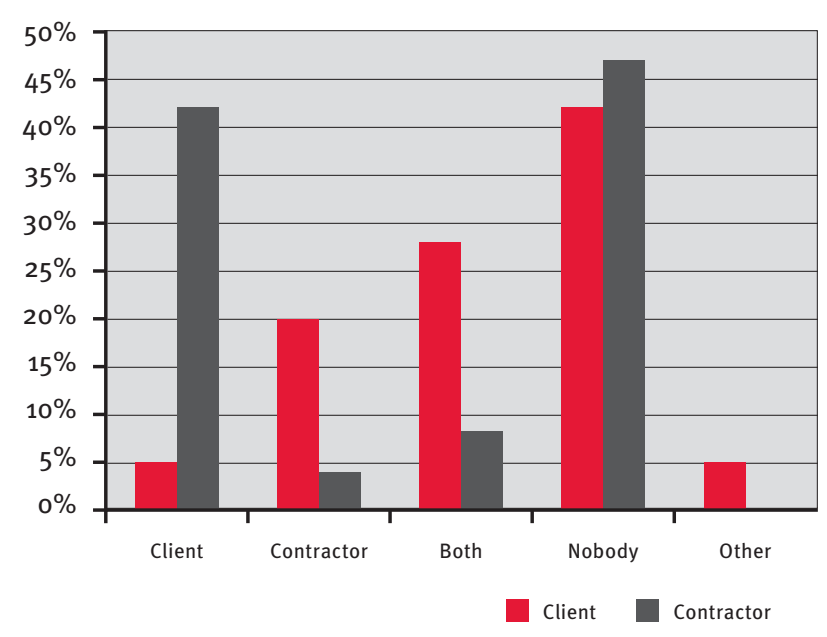

Figure 1: Winners in the current situation

(Spang et al., 2009)

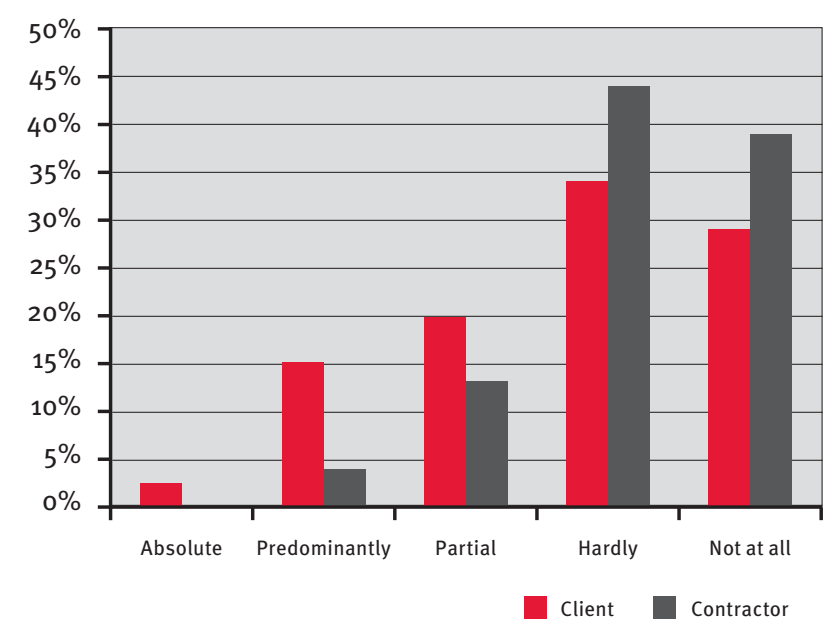

Figure2: Satisfaction of participants with the current situation (Spang et al., 2009)

\section{Current situation in the construction industry}

The situation in the construction industry, especially in complex projects, often seems very similar worldwide (Spang, 2009). There is very little cooperation between the client and contractor and both sides complain about the growing number of conflicts. The industry is still far away from partnering aspects being implemented in project execution. Different authors have grappled with this situation (Egan, 1998; Girmscheid, 2005; Ingram and Bennet; 1997; Spang, 2006 and Spang and Riemann, 2011) and have pointed out the following significant problems resulting from that imperfection:

- Mutual dissatisfaction with the current situation

Distrust between the contracting parties

Dusiness expertise is less used because of the exclusive focus on price

- Rising cost of supplemental management or defence against claims

- Growing number of conflicts and litigations

- Contractor's low profit margins together with excessive risk of insolvency

The field study conducted in 2006 on the construction industry in Germany by the Chair of Project Management at the University of Kassel as part of the re- search project entitled "Partnerschaftliche Projektabwicklung bei Infrastrukturprojekten zwischen Auftraggeber und Auftragnehmer" (Guideline for partnership between client and contractor in infrastructure projects in Germany ("The guideline")) was also able to support the above mentioned conclusion (Spang et al., 2009). This research has analysed 126 answers from practitioners received on a questionnaire addressed to the various stakeholder in the industry. 57 of the participants worked on the client's side, another 54 were contractors and the remaining 15 answers came from third party groups, like consultants or lawyers. More than $40 \%$ of those surveyed in this research indicated that they see no winner from the current situation (cf. Fig. 1). Another $42 \%$ of the contractors were of the opinion that the clients are the winners. In contrast only $20 \%$ of the clients see the contractors as the winners. $27 \%$ of them also see both of them as winners, a situation that a cooperative project management tries to improve. The participants were also asked about their satisfaction with the current situation. More than $60 \%$ of clients and over $80 \%$ of contractors indicated that they are hardly or not at all satisfied with the current situation (cf. Fig. 2).

The frequency of use of different conflict resolution procedures was subject of another question. As can be seen from Fig. 3, conflicts first and foremost are negotiated on the project or company manager's level and if they are unable to settle, the cases are referred to court. Extrajudicial and sometimes even partnership-based methods such as mediations, arbitrations or arbitration tribunals are applied only in exceptional cases.

Sometime later, in summer 2007, the German Association to Develop Construction Court Proceedings and Construction Law (Deutscher Baugerichtstag) commissioned a survey which also questioned participants in the German construction industry but particularly about the current situation in conflict resolution and about the options currently under discussion (Deutscher Baugerichtstag, 2007, Gralla and Sundermeier, 2008). 888 replies have been analysed where clients and contractors each were represented at about $27 \%$ each. The remaining $46 \%$ of those surveyed were formed by "Third parties", such as solicitors and technical experts. Participants were queried, among other things, about their opinion on state courts, which in Germany still represents the most used instrument of dispute resolution if the parties themselves are unable to settle amicably. The procedure here is as follows:

A party brings its suit before the Magistrate's Court or Regional Court 


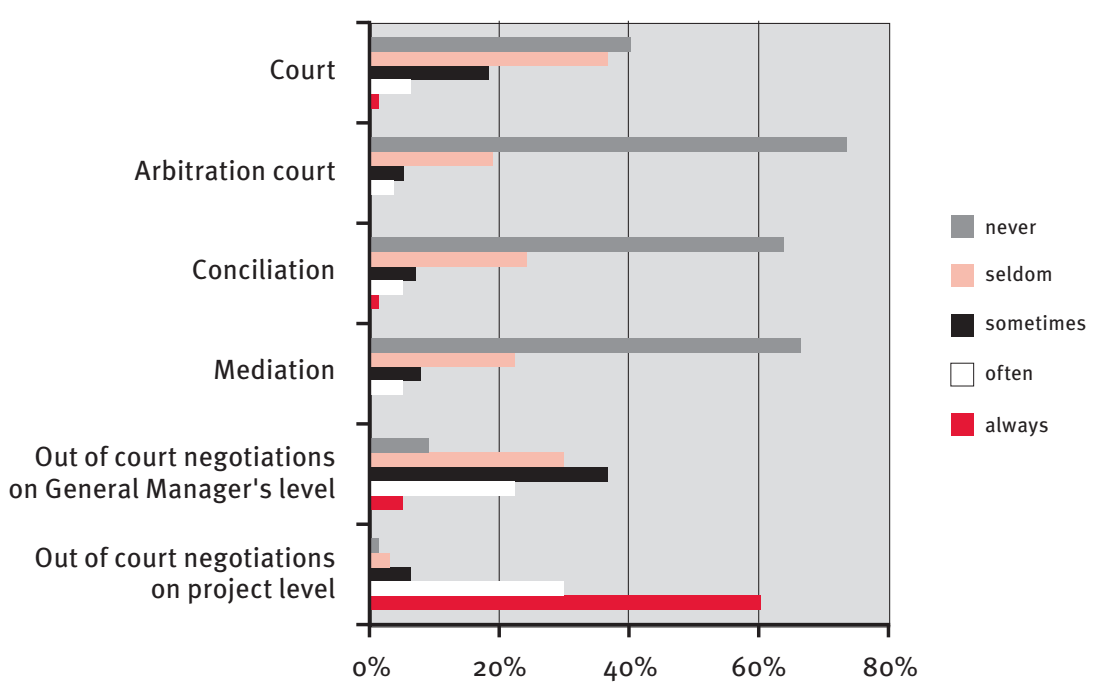

Figure 3: Frequency of use of different conflict resolution alternatives (Spang et al., 2009)

(depending on the value in litigation). An exchange of letters and statements then takes place where both parties describe their position to the court of law. A verbal hearing is then held where the parties clarify their positions once again. If the judge is unable to make the parties reach an agreement at this stage, then the court renders its decision. Each of the parties can appeal this judgment within a certain period, following which proceedings before the next higher instance takes place. Internal party costs and litigation costs are very difficult to estimate and can very rapidly increase if the proceedings drag on over a long pe(Gralla and Sundermeier, 2008). Supplementary to this the apparently widespread dissatisfaction exists over the quality of judicial decisions.

The outcome of the research on the traditional, confrontational dispute resolution through state courts then comes as no surprise. The three groups of professionals mentioned above were unanimous in indicating at about $60 \%$ of the votes that they are dissatisfied with the current situation in German courts (cf. Fig. 4), whereas those who have already once come into contact riod because of, say, overloaded courts with arbitration tribunals were predominantly satisfied (cf. Fig.5).

Then to the question whether mandatory extrajudicial dispute resolution procedures should be introduced, those surveyed answered that they wanted a change. This question was answered with a "yes" by $70 \%$ of all participants, and contractors comprised the greatest portion ( $82 \%$ ) of those who did so.

The overall impression from the survey is that the call for new and innovative dispute resolution procedures is becoming louder and louder (Spang, 2009). The third annual meeting of the German Association to Develop Construction Court Proceedings and Construction Law in 2010 addressed a recommendation to legislators for future construction projects to have an adjudication procedure passed before any court proceedings can be initiated ( 3 . Deutscher Baugerichtstag, 2010). For clarity the major methods of alternative dispute resolution, including the adjudication procedure, are briefly presented in the following section.

\section{Alternative dispute resolution procedures}

There are numerous procedures for alternative dispute resolution with terms sometimes applied differently.

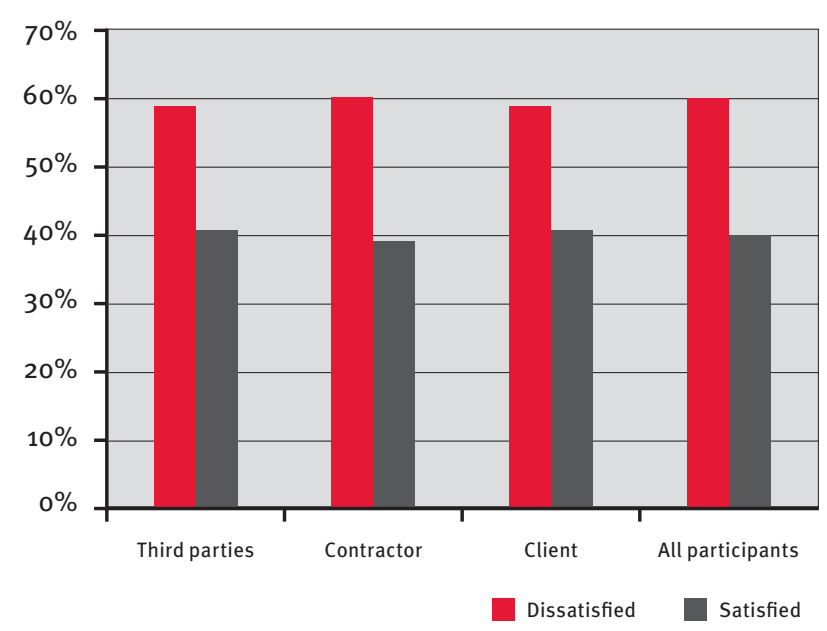

Figure 4: Opinion on state courts

(Deutscher Baugerichtstag, 2007)

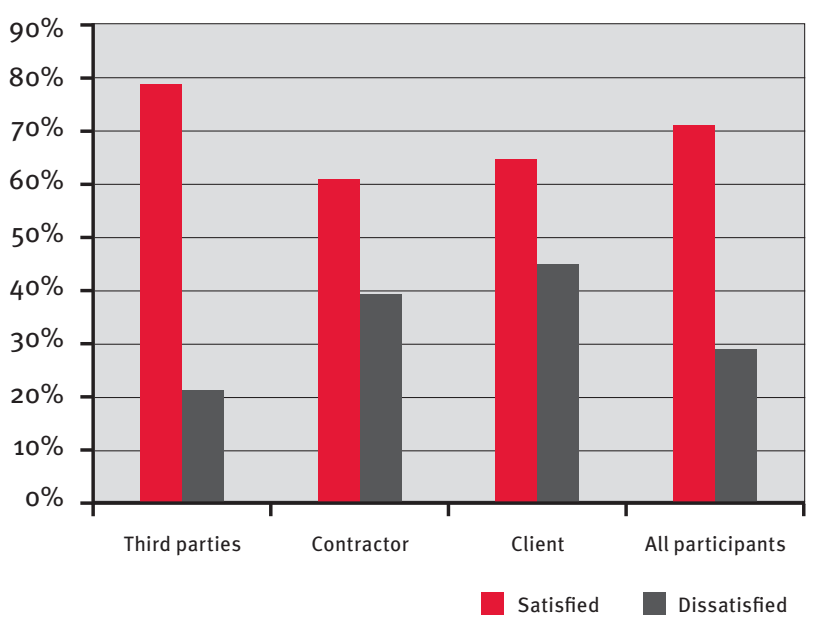

Figure 5: Opinion on arbitration tribunals (Deutscher Baugerichtstag, 2007) 
However, many procedures are hybrids of a few basic forms to which we will now limit ourselves here.

\section{Direct Negotiations}

Direct Negotiations represent the simplest and most frequently applied dispute resolution procedure (cf. Fig. 3). Opposing parties here negotiate without resorting to a conflict negotiator. A party may include third parties such as an expert as advisor. These can help the parties to explain their respective position. The commissioning party bears the costs of the expert opinion. In addition, this procedure involves no other external litigation costs. However, depending on the parties' willingness to negotiate and readiness to compromise, the procedure can drag on for a long time, in major disputes often beyond the physical completion. It therefore makes sense to draw up a road map in advance. Should the parties then fail to find a solution in the agreed upon time, another dispute resolution procedure must be chosen.

\section{Mediation}

The extrajudicial method of mediation was first used in construction projects in the US (Duve, 2007). In case of dispute, both parties initially appoint one (or several) independent third party

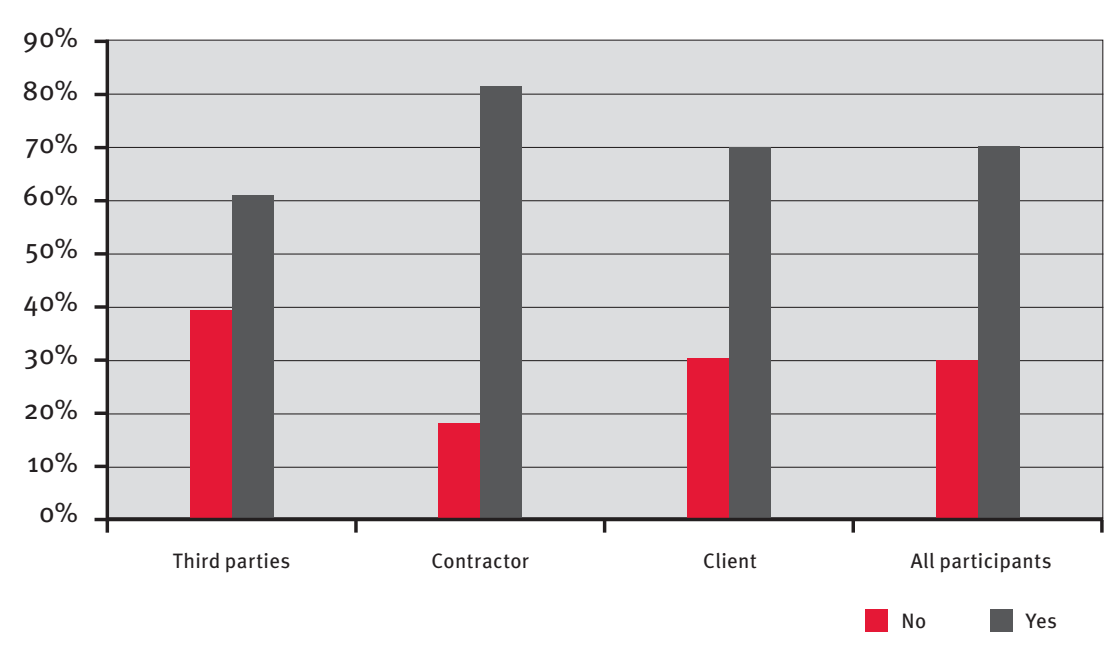

Figure 6: Opinion of construction industry participants on mandatory extrajudicial conflict resolution procedures (Deutscher Baugerichtstag, 2007) (third parties) who take(s) charge of the procedure, especially the mediation negotiations. The goal of mediation is for the parties to come to an agreement under the moderating direction of the mediator. In contrast to the arbitration procedure, the mediator takes no position in the dispute and also makes no decision. If no agreement is reached in the mediation, the procedure is aborted and the parties must resort to another dispute resolution procedure. Since the mediation procedure is only insufficiently formalized, its duration depends very much on how willing the parties are to negotiate. The parties usually bear the costs of the procedure, meaning primarily the fees of the mediator, in equal parts. Each of the parties covers its own party representation costs.

\section{Conciliation}

Just like in all the following concepts of alternative dispute resolution, conciliation should also be expressly agreed upon between the parties before it is initiated by one of them (Duve, 2007). Preferably such agreement should take place at the beginning of the project but it can also be made once a concrete dispute arises. A neutral person (sole conciliator) appointed by the parties or an entity consisting of neutral persons (board of conciliators, usu- ally three) presides over negotiations on conflicts between contracting parties advising them. Conciliators don't need to be lawyers. However, they must have good knowledge of construction law (Mnookin, 1998). The objective of the negotiations is that all parties find a common solution. If this cannot be reached, the conciliator will suggest a solution in the hopes that it would garner the greatest consent from all parties. If this solution is adopted by all parties, then it becomes binding, but if it is rejected even by one party only, the procedure has failed. Litigation costs, in turn, are borne by all parties in equal parts (Duve, 2007) and there is no obligation to be represented by legal counsel.

\section{Adjudication}

Adjudication proceedings are similar to conciliation; however the independent adjudicator (or adjudicators) appointed by the parties has to make a decision on the dispute within a limited time based on facts of the case and on the contract. This decision is binding for all parties and can be overturned only by an (arbitration) court. This binding effect requires from adjudicator's a high level of knowledge and expertise on construction law and execution of the works. The procedure is also more formalized than mediation or conciliation. The adjudicator receives broader rights in acquiring information. The adjudicator can, for example, prescribe site visits, request documents and question third parties about the facts of the case (Deutscher Baugerichtstag, 2010). In most cases there is no obligation to be represented by legal counsel. For constitutional reasons, the possibility to appeal the adjudication board's decision through the court is imperatively in Germany.

\section{Arbitration}

In the arbitration procedure too parties initially have the greatest possible say on the appointment of the decisionmakers (arbitrator) and to a certain ex- 
tent on the procedure as well. However, (in Germany) at least one member of the arbitration tribunal must be a lawyer. The task of the arbitration tribunal procedure is to arrive at the most objective possible, final and binding decision on a dispute based on the facts of the case and on the contract. An appeal is possible only under very limited circumstances. In turn this requires the arbitrators to strictly obey the rules of "due process", for example to allow the parties to fully present their case. As a consequence, arbitration procedures often take several years and incur relatively high costs for example by the arbitrators, technical experts, solicitors and in-house employees involved. Costs allocation finally depends on which of the parties prevails.

of the above-mentioned alternative dispute resolution methods adjudication is little known in Central Europe. It, -respectively the so-called dispute board-should therefore be described in more detail below.

\section{Experience on dispute boards from abroad \\ History and diffusion}

Circumstances, especially the required time for and hence the associated costs of following up disputes in court, led to the development of the dispute board concept in the US at the end of the 6os. It was initially applied on the local construction market. Indeed, it is often problematic as well, where required, to have a local court of law to decide on a dispute to an international project. For this reason, the World Bank also supported this idea and implemented it for the first time on a project it was financing in 1980: the construction of a hydropower plant in Honduras (Chapman, 2004).

In the 1990 s the Fédération International des Ingénieurs-Conseils (FIDIC) adopted the concept and formulated standard clauses and rules of dispute adjudication in its standard contracts for construction services in 1995 (FIDIC,
1996). From the same year onwards the World Bank made the dispute board concept a fixed component of its procurement directives. Since a dispute board (DB) must be provided on all projects the World Bank is financing and with a contract value exceeding US\$ 50 million. From 2006 many other development banks have taken the FIDIC standard contracts in the form of the "Multilateral Development Bank Harmonised Edition" (FIDIC, 2010) as the basis for projects that they promote. After some developments the International Chamber of Commerce (ICC), Paris also published its own rules of adjudication for international use in 2004 (International Chamber of Commerce, 2004). Adjudication was conceived in Great Britain solely for the local construction market. In 1998 it even got a statutory framework in the form of the "The Housing Grants, Construction and Regeneration Act 1996" (The Housing Grants, 1996). This Act normally provides an extremely short procedure of 28 days only between the referral of a dispute and the decision on it by the adjudicator.

\section{Experiences with the DB}

Experiences with the various dispute board/adjudication concepts mainly exist from outside of Germany.

According the evolution of the concept it is initially the construction market in the US where it is used. The Dispute Review Board (DRB) gains in popularity there, offering a cost-effective option for avoiding exorbitant costs in case of a legal dispute regarding domestic construction projects. Many public clients have already adopted the DRB concept in their standard contract conditions, that is, for a board whose decision initially constitutes a recommendation only and has no binding effect. Only if none of the parties raises an objection within a certain period will the decision become binding. In some regions courts accept a dispute in construction affairs only if the dispute has previously passed through a DB procedure.
The Dispute Resolution Board Foundation (DRBF) reports that the "concept has a success rate of roughly $90 \%$ " (DRBF). This means that the parties reach a settlement based on the DRB recommendation in about $90 \%$ of their disputes.

In Great Britain the DB, which takes the form of adjudication, is obligatory if one of the parties in construction matters wishes to apply it. This concept is intended to mainly bring small companies, especially subcontractors, quickly and urgently back to liquidity. Based on statistics of the Glasgow Caledonian University (Research Analysis of the Progress of Adjudication), parties settle on the basis of these decisions in about $80 \%$ of cases, meaning an (arbitration) court procedure is avoided. In case of appeal, the courts uphold the adjudicator's decision in about $80 \%$ of the cases (Kennedy and Milligan, 2003).

With regard to international construction projects, one of the co-authors has long years of experiences with dispute boards which he first summarized and published in a report in 2006 (Köntges, 2006). This study was based on information from a number of the author's own projects and strange projects. It dealt predominantly with project-related DRBs or DABs (project-related, permanent boards, in contrast to ad-hoc boards which are formed spontaneously in case of dispute) with an international context in countries without special legislation on adjudication. A total of three criteria were defined eventually in the analysis to assess the success of the DB concept: expenditure of time and cost as well as rate of settlement. Given the often high cost of logistics and communication in international projects, a dispute needs 90 to 150 days from its referral to the board of adjudicators up to the board's reasoned decision. This expenditure of time arises even though the FIDIC provides 84 days for it in its rules (cf. FIDIC, 1996 and FIDIC, 2010). Arbitration procedures for other proj- 
ects, on the other hand, required 1.5 to 8 years before an award was rendered.

In all the cases analysed the overall cost of the dispute board procedure remains below $2 \%$ of the respective contract value. This includes the regular visits to the project site in case of permanent dispute boards. In comparison, an arbitration procedure on other projects at the same period regularly costs more than $5 \%$ of the contract value of the relevant projects.

The same analysis is also unequivocal regarding the rate of settlement. In about $75 \%$ of contracts analysed the dispute board's decision forms the basis of a settlement between the parties. Only in about $25 \%$ of contracts does an (arbitration) court procedure take place (Köntges, 2006), a figure that is similar to the one that the Dispute Resolution Board Foundation (DRBF) from the US reports described above. However, in the same period about $60 \%$ of the contracts which provide no DB ended up in the (arbitration) court (Köntges, 2006).

The significance of the dispute board for international projects can also be recognized from the fact that there are contractors for which the lack of a so-called DB clause in a tender procedure constitutes a deal breaker. No offer is submitted if there are no prospects for adopting such a clause in the new contract.

Dispute boards are used in various medium-sized or large-scale long-term work contracts regarding plant engineering, construction, building and civil construction and infrastructure activities, with general contractors and subcontractors. They can also be found in PPP and BOT contracts even though "The Housing Grants, Construction and Regeneration Act 1996" excludes these categories in Great Britain. This concept has also been found since in other sectors such as in sophisticated IT development projects.

Additionally, for example, at the DRBF Conference in April 2011 in Vienna, various DB procedures for domes- tic construction projects were reported in countries with a civil law background such as Austria, Switzerland and Germany. However, general conclusions cannot yet be made because of their low and statistically unrepresentative number.

\section{Partnering and conflict} resolution in publicly financed traffic infrastructure projects in Germany

To counter the negative situation described above and get away from confrontational project execution to one that is based on partnership, a research project was launched in 2005 with support of the German Federal Ministry of Transport, Building and Urban Affairs (BMVBS), the three main construction associations, large client organisations as well as many construction companies. Based on the positive experiences from abroad, which show faster, more cost-effective and completely more satisfactory conflict resolution, the chair of Project Management of the University of Kassel in cooperation with practitioners from the construction industry developed a multi-stage partnering concept which beside others involves the (extrajudicial) adjudication approach. This partnering concept was laid down in a guideline for public financed infrastructure projects, in 2008. This partnering guideline consists of a preamble and seven elements which cover regulations among others for the following areas:

- Clear contractually agreed scope

$\checkmark$ Defined processes in case of changes from the contractually agreed scope

- Management of risks

$>$ Common information management

- Clear allocation of responsibilities

> Management of conflicts / dispute resolution

$\checkmark$ Incentive systems for value engineering

The conflict resolution element contains a cascade model, including an adjudication concept, to be applied for all differences in opinion that occur (cf. Figure 7).

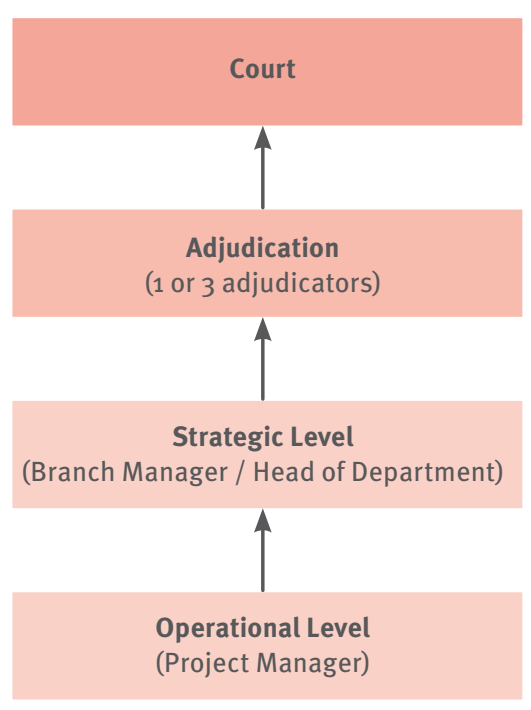

Figure 7: Cascade model for conflict resolution (Spang et al., 2012)

The first stage, the operating level, is formed by the project managers from the client and the contractor. These persons are acquainted with the project in the best possible way and differences as much as possible should be resolved at this level. If participants do not arrive at any result within an adequate time, both parties or even just one of the two invokes the next level and pass the issues on to persons from the higher management, appointed already at the beginning of the project. These, on their part, will now try to find a solution to the issues under dispute. If this is also not successful within an adequate period, one party may invoke the adjudication board as stage three. The number of adjudicators depends primarily on the scale and the complexity of the construction project. Both parties establish their number of board members jointly based on the client's recommendation.

In case of conflict both parties present the circumstances of their problem in writing. The adjudicators then invite both parties to a hearing. Both parties are heard here presenting their positions verbally regarding the facts of the case and their arguments. On the base of the facts of the case and the contractual provisions they obtained by this 
hearing and by the written statements the adjudicators write a reasoned and provisionally binding decision. If within a specified period one party objects to the decision, it is thereafter free to resort to a competent court of law. Such option is inalienable according to German law. However, the adjudicator's decision remains valid until a competent court of law overrides it. Until then both parties must act in accordance with this decision.

The board of adjudicators on a respective construction project can be set- up in different ways. On the one hand, it can be appointed "ad-hoc" for the particular dispute to rule only on this dispute. The adjudicators are therefore involved in the project only upon the submission of a dispute through the strategic level. On the other hand, the board can be appointed by the parties at the beginning of the project to follow it up on an ongoing basis. The adjudicators then visit the project site regularly and regularly receive information on its progress including issues of potential conflict.

The variant involving a permanent board of adjudicators on a project has the decisive advantage of deciding on and resolving conflicts very fast since the members are already acquainted with the project and its environment. However, the disadvantages of the permanent dispute board are higher costs from the adjudicators due to their ongoing involvement. Therefore, special attention must be paid to the consideration of which option is most suitable. If there are several items of conflict already to be expected at the start of the project and fast adjudicator's decisions are needed to avoid or minimize followup costs due to work stoppage or delay for example, the higher costs from a permanent board of adjudicators should be acceptable. Normally these costs are eventually paid off at the end. However, if the risk of conflicts is considered low and decisions are not necessarily needed soon for project execution, the costs from a permanent board of adjudicators may be saved. The disadvantage of any possible "slower" decision must be considered whatever the choice. At any rate, the advantage of both options, the permanently integrated and "adhoc" adjudication board, with respect to litigation is that decisions come faster, the procedure is more cost-effective and the rate of acceptance of adjudicator decisions by the parties is higher. Another very important aspect is that these circumstances contribute to a better atmosphere between the parties, which eventually leads to increases in efficiency and improved product and project quality.

\section{Experience with pilot projects to the research program}

In the beginning of 2009, as part of the above-mentioned guideline, two road projects were selected to test the application of the guideline. One of them, the expansion of a provincial road from two to four lanes with an investment volume of around $€ 5 \mathrm{~m}$, has already been finished. The other involves the construction of an $8 \mathrm{~km}$ section of highway at an investment volume of about $€ 45 \mathrm{~m}$. This project is close to completion. In both projects the parties have opted for the permanent involvement of adjudicators, whereby in the smaller project a single member board and in the larger one a three member board was appointed.

No dispute was referred to adjudication in the case of the provincial road project during its execution. All conflicts were resolved on the first, the operational level. In the highway project the parties were also able to resolve many conflicts on the first or the second level. Till now three substantial conflicts were referred to the board of adjudicators and have been decided. Here, following the procedure described above, both parties presented their respective position on the disputed circumstance in written form to the adjudicators, with the request to decide on the merits of the cases. With this initial information available, a joint hearing took place where both parties were again able to explain their arguments regarding the claims. The adjudicators deliberated on this basis and gave their provisional opinion on how their decisions would be. This provided the impetus for the parties in the first case to enter into negotiations once again and to reach a settlement on the entire problem. In the second case the parties also accepted the adjudicator's explanations regarding the merits of the case but they were unable to agree on its quantum. Instead the parties expanded the brief of the adjudicators to the effect that they should determine the quantum as well. Afterwards the adjudicator's decision on the merits and the quantum is provisionally binding for both parties and could be overruled only by court as described above. However, the decision in this case was not appealed within the contractually stipulated period. Therefore this decision also became final and binding eventually. Currently the merits and the quantum of a third, even more significant claim are under review by the adjudicators.

This year the parties also benefit of the adjudicators being permanently available in a settlement approach actually not expressly foreseen in their contract. They jointly approached the adjudicators to get an even faster but at the same time more cost effective informal opinion regarding a smaller problem. The parties remembered the first adjudication cases, where they were able to find a solution on the basis of the arbitrator's first comments. On this basis they asked the adjudicators for their informal comments also on that limited dispute. An approach, the authors feel, that exploits best the advantage of a permanent dispute board if available on the project.

The comparatively low number of conflicts referred to the adjudicators can be attributed not only to the multistage model for conflict resolution. It lies primarily with the preventive mea- 
sures integrated in the guideline overall which often prevented conflicts from emerging. So, for example, following the site progress meetings, meetings of a risk committee takes place where the parties consider current and potential risks. In addition, joint (client and contractor) workshops are hosted every six months where an open exchange on problems takes place outside the normal construction routine. The early appointment of responsible managers and the establishment of a road map applicable in case of deviations from the construction target were able to defuse possible items of conflict right from the start. Experience shows that all these elements contribute to more open communication and hence to an improvement of the atmosphere among participants.

\section{Summary and outlook}

The call for alternative methods of dispute resolution is becoming louder and louder. The vast majority of players in the construction industry are dissatisfied with dispute resolution by the courts. Experience from outside of Germany and the results so far from pilot projects confirm that the existence of an adjudication board and where applicable, their informal provisional opinion or independent, professional decision motivates the parties to reach a settlement. In the cases described above this allowed to solve emerging conflicts not only faster than by court proceedings but also to find solutions which are more acceptable to both parties. None had to come out as 'the loser', as it is often the case following court rulings, which would not have been beneficial to the atmosphere between the parties.

It should also be noted that in the projects described above, because of the preventive measures such as the risk committee, the joint workshops and because of the conflict resolution model, there were no disruptions such as those caused by the lack of decision or a massive build-up of problems. This, in turn, had a positive effect on the relationship between the parties and of course on the project's progress and the construction costs as well.

There is the hope that this development continues and differences in opinion can thus mostly be solved quickly and amicably. In this case, large sums of litigation costs can be saved, on the one hand. Cost for claims management that otherwise often continues even far after the completion of the construction activity are clearly minimized, on the other hand.

\section{References}

Deutscher Baugerichtstag (2010); Empfehlungen des 3. Deutschen Baugerichtstages an den Gesetzgeber. Hamm (Westf.),

Chapman, P. (2004), Conference paper, 4th International DRBF Conference, Berlin.

Deutscher Baugerichtstag (Ed.) (2010), Diskussionsvorschlag des Deutschen Baugerichtstages e.V. für eine AdjudikationsOrdnung für Baustreitigkeiten (AO-Bau / DBGT) auf vertraglicher Grundlage.

Deutscher Baugerichtstag e.V. (Ed.) (2007), Umfrage zum Bedarf alternativer Konfliktbewältigungsmodelle am deutschen Baumarkt.

Dispute Resolution Board Foundation (DRBF), Seattle, 98188-2441 USA, www.drb.org

Duve, H. (2007), Streitregulierung im Bauwesen, Werner Verlag, Köln.

Egan, J. (1998), “Rethinking Construction”, The report of the construction Task Force. Department of Trade and Industry, London.

Fédération International des IngénieursConseils (FIDIC) (2010): Conditions of Contract for Construction, Multilateral Development Bank Harmonised Edition, Lausanne 2006; Revised edition

Fédération International des Ingénieurs-Conseils (FIDIC) (1996), Supplement to Fourth Edition 1987 of Conditions of Contract for Works of Civil Engineering Construction, Lausanne.

Girmscheid, G. (2005), "Partnerschaften und Kooperationen in der Bauwirtschaft”, Bauingenieur, 8o, pp. 103-113.

Gralla, M. and Sundermeier, M. (2008), „Adjudikation - außergerichtliches Streitlösungsverfahren für Baukonflikte auf gesetzlicher Basis? - Eine empirischbaurechtliche Betrachtung“, Bauingenieur, 83, pp. 238-247.
Ingram, I. and Bennet, J. (1997), “Book Reviews”, Construction Management and Economics, 15, pp. 304-306.

International Chamber of Commerce (2004), Dispute Board Rules, Paris.

Jannadia, M.; Assaf, P.; Bubshait, A. and Naji, A. (2000), "Contractual methods for dispute avoidance and resolution (DAR)", International Journal of Project Management, 18, pp. 41-49

Kennedy, P. and Milligan, J.L. (2003), “Research analyses of the progress of adjudication based on returned questionnaires from adjudicator nominating bodies (ANBs) and on questionnaires returned by adjudicators.", School of the Built and Natural Environment, Adjudication Reporting Centre, Glasgow Caldedonian University, Report No 5, Glasgow.

Köntges, H. (2006), “International Dispute Adjudication - Contractors' Experiences”, ICLR, 23, pp. 289-390.

Mnookin, R. (1998), “Alternative Dispute Resolution”, Harvard Law School John M. Olin Centre for Law, Economics and Business Discussion Paper Series. Paper 232.

Spang, K. (2006), „Innovative Projektabwicklung bei Bauprojekten - Plädoyer für einen Paradigmenwechsel“, Bauingenieur, 81, pp. 117-125.

Spang, K. (2009), “Designing the relationship between contractor and client to partnership", ISEC-Conference, Las Vegas, Nevada USA.

Spang, K. and Riemann, S. (2011), “A guideline for partnership between client and contractor in infrastructure projects in Germany", in Proceedings of MISBE-Conference, Amsterdam, Netherlands.

Spang, K.; Riemann, S. and Faber, S. (2009), „Partnerschaftliche Projektabwicklung bei Infrastrukturprojekten - Feldstudie am Lehrstuhl für Projektmanagement“, Schriftenreihe Projektmanagement, Heft 8, Kassel.

Spang, K.; Riemann, S. and Köntges, H. (2012) "A Partnership-Based Approach to Handling Conflicts in Infrastructure Projects", in Proceedings of BrennerCongress 2012, pp.6978, Innsbruck, AT.

The Housing Grants, Construction and Regeneration Act 1996 (1006), delivered by The National Archives, www.legislation.gov.uk 